Bangladesh J. Bot. 48(2): 307-313, 2019 (June)

\title{
BIOACTIVITIES OF ADINA CORDIFOLIA (ROXB.) HOOK. F. - GROWING IN BANGLADESH
}

\author{
Faiza Tahia, Md Al Amin Sikder, Md Abdullah Al-Mansur ${ }^{1}$ \\ AND Mohammad A RaShid \\ Phytochemical Research Laboratory, Department of Pharmaceutical Chemistry, \\ Faculty of Pharmacy, University of Dhaka, Dhaka-1000, Bangladesh
}

Keywords: Adina cordifolia, Isoscopoletin, Umbelliferone, $\beta$-sitosterol, Minimum inhibitiory concentration, Antidiarrheal, Analgesic, Hypoglycemic

\begin{abstract}
A total of three compounds were isolated from the methanol extract of bark of Adina cordifolia (Roxb.) Hook. f. growing in Bangladesh and characterized as isoscopoletin (1), umbelliferone (2) and $\beta$-sitosterol (3) by analysis of high field NMR spectral data as well as co-TLC with authentic compounds. The minimum inhibitory concentration (MIC) of different extracts of bark of A. cordifolia was evaluated against three Gram positive and Gram negative pathogenic bacteria. The carbon tetrachloride soluble fraction showed the lowest MIC value $(7.81 \mu \mathrm{g} / \mathrm{ml})$ against Sarcina lutea as compared to $1.25 \mu \mathrm{g} / \mathrm{ml}$ for ciprofloxacin. The crude extract demonstrated significant antidiarrheal, hypoglycemic and peripheral analgesic activities at 200 and 400 $\mathrm{mg} / \mathrm{kg}$ body weight in mice. On the other hand, the crude extract of bark of A. cordifolia revealed mild central analgesic activity.
\end{abstract}

\section{Introduction}

Adina is a genus with 7 species of flowering plants belonging to Rubiaceae. They are shrubs or small trees, native to East and Southeast Asia. Adina cordifolia (Bengali name: Keli Kadam, Haldu, Rangkat; English name: yellow teak, saffron teak) is reported to occur in Bangladesh, India, Ceylon, Thailand, and Burma, and is usually found scattered in mixed deciduous forests (Mabberley 2008, Ahmed et al. 2009). Fresh bark is traditionally ground with brown sugar and taken internally for stomachache. Bark and leaves are used for cholera, cold, cough, fever, headache, scars and yellowish skin and urine complaints. Previous phytochemical study led to the isolation and characterization of 10-deoxyadifoline, 10-deoxycordifoline, cordifoline, adifoline, dihydroxytetra- $O$-methyl flavones, napthaquinone and adinine (Prakash et al. 2015).

As part of previous continuing studies with medicinal plants of Bangladesh (Sikder et al. 2013, Faiza et al. 2015, Ibrahim et al. 2018), in the present study, isolation of isoscopolein (1), umbelliferone (2) and $\beta$-sitosterol (3) is reported from $A$. cordifolia for the first time. The crude methanol extract of the bark of $A$. cordifolia growing in Bangladesh as well as its aqueous and organic soluble fractions were studied for their minimum inhibitory concentration (MIC), analgesic, hypoglycemic and antidiarrheal activities and the results of the preliminary investigation are presented in the paper.

\section{Materials and Methods}

${ }^{1} \mathrm{H}$ NMR spectra were acquired on Ultra Shield Bruker $400 \mathrm{NMR}$ instrument, using $\mathrm{CDCl}_{3}$ and the chemical shifts are reported in ppm with respect to TMS or residual non-deuterated solvent signals. RV10 Basic rotary evaporator (IKA, Germany) was used for evaporation. All the

*Author for correspondence: <r.pchem@yahoo.com>. ${ }^{1}$ Bangladesh Council of Scientific and Industrial Research (BCSIR), Dr. Qudrat-e-Khuda Road, Dhanmondi, Dhaka-1205, Bangladesh. 
solvents were of Merck (Germany) and lipophilic Sephadex LH-20 used for the gel permeation chromatography was of Sigma Aldrich.

Acetic acid (Merck, Germany), Tween-80 (BDH Chemicals, UK), normal saline solution (Beximco Infusion Ltd. Bangladesh), morphine (Gonoshastho Pharmaceuticals Ltd., Bangladesh), diclofenac sodium, glibenclamide and loperamide (Square Pharmaceuticals Ltd., Bangladesh) were used in the investigations.

The experimental works were conducted at Phytochemical Research Laboratory, Department of Pharmaceutical Chemistry, Faculty of Pharmacy, University of Dhaka. Bark of A. cordifolia was collected from the campus of the University of Dhaka, Bangladesh, in April 2013. Voucher specimen (DACB No. 44990) for the plant has been maintained in Bangladesh National Herbarium, Dhaka, Bangladesh for future reference. The bark was first dried in sun and then ground into a coarse powder using a grinding machine.

The powdered bark $(1000 \mathrm{~g})$ was soaked in 3.0 litre of methanol for 7 days and then filtered through a cotton plug followed by Whatman filter paper No. 1 . The extract was concentrated with a rotary evaporator. A portion $(5 \mathrm{~g})$ of the concentrated methanol extract was fractionated by the modified Kupchan partitioning protocol (Miah et al. 2018) into petroleum ether (PESF) (0.67 g), carbon tetrachloride (CTCSF) (0.53 g), chloroform (CHSF) (0.35 g) and aqueous (AQSF) (2.45 g) soluble fractions.

The methanol extract of $A$. cordifolia and its organic soluble fractions were primarily subjected to for TLC. The extractives with satisfactory resolution of components (carbon tetrachloride and petroleum ether soluble fractions) were selected for gel permeation over lipophilic Sephadex LH-20 and preparative thin layer chromatography over silica gel $\left(\mathrm{F}_{254}\right)$. Then chromatographic fractions were analysed over TLC plates using different mobile phase including $n$-hexane: dichloromethane, toluene: ethyl acetate and methanol: chloroform. The fractions with similar characteristics from TLC analysis were combined together and subjected for PTLC analysis over silica gel $\left(60 \mathrm{~F}_{254}, 20 \times 20 \mathrm{~cm}\right)$ plates. This yielded 3 pure compounds (1-3) (Fig. 1). The structure of the isolated compounds was solved by extensive analysis of their ${ }^{1} \mathrm{H}$ NMR spectral data, comparison with published values and co-TLC with authentic sample.

Swiss-albino mice of either sex aged 4 - 5 weeks were used for the experiment. The average weight of the mice was $20-25 \mathrm{~g}$. All efforts were made to minimize animals suffering of the animals used in the experiments. The mice were kept in standard environmental condition (at 24.0 $\pm 1^{\circ} \mathrm{C}$ and $55-65 \%$ relative humidity and $12 \mathrm{hrs}$ light/12 hrs dark cycle) for a week for acclimatization after their purchase and fed with rodent feed collected from the ICDDR,B and water ad libitum. The extractives of the plant were dissolved in $1 \%$ Tween 80 in $0.9 \%$ normal saline separately at a concentration of $10 \mathrm{mg} / \mathrm{ml}$ and the required dose was administered orally according to the weight of the mice.

Minimum inhibitory concentrations (MICs) are defined as the lowest concentration of antimicrobial that will inhibit the visible growth of a micro-organism after overnight incubation and is generally regarded as the most basic laboratory measurement of the activity of an antimicrobial agent against an organism (Turnidge et al. 2003). The MIC was determined for different extractives by serial tube dilution technique (Jennifer 2001). Thirteen test tubes were taken and labelled from 1 to 10 and the rest three as $\mathrm{T}_{\mathrm{m}}$ (only medium), $\mathrm{T}_{\mathrm{mc}}$ (medium + extractive solution) and $\mathrm{T}_{\mathrm{mi}}$ (medium + inoculum). Calculated amount of broth was taken in each test tube and extract was added by serial dilution from 0 to concentration $1000 \mu \mathrm{g} / \mathrm{ml}$. Lastly, the inoculum was added, shaken and incubated at $37^{\circ} \mathrm{C}$ for $24 \mathrm{hrs}$. After $24 \mathrm{hrs}$ the test tubes were checked for microbial growth and clear test tubes compared to McFarland turbidity standards were marked for 
MIC determination. The lowest concentration of extract preventing turbidity was considered to be the MIC.

Central analgesic activity of methanol extract of $A$. cordifolia, was evaluated following the procedure described by Islam et al. (2016). Test samples and control (morphine) were given orally by means of feeding needle to the mice. A constant heat stress was applied to mice tail, which acted as pain stimulus. When the stimulus exceeded the threshold, rat showed a quick withdrawal of its tail. The reaction time required by the mice to deflect their tails, termed as tail immersion time, was recorded. Analgesic compounds elongate this response time which was recorded to observe the central analgesic action.

Peripheral analgesic activity was evaluated by determining the ability of the test samples to inhibit acetic acid induced abdominal writhing in mice. The experimental process for the methanol extract of A. cordifolia, was conducted as previously described by Kaushik et al. (2012).

Antidiarrheal activity was assessed by the method developed by Shoba and Thomas (2001), where castor oil was used to induce diarrhea in mice.

The lowering of blood glucose level of the experimental animals was measured by tail tipping method (Durschlag et al. 1996) on Swiss albino mice. The experimental animals were randomly divided into four groups (I to IV) consisting of five mice in each group. Test samples at 200 and $400 \mathrm{mg} / \mathrm{kg}$ body weight were administered to evaluate the hypoglycemic activity. Standard glibenclamide was used at a dose of $10 \mathrm{mg} / \mathrm{kg}$ b.w. Each mouse was weighed properly and the doses were adjusted accordingly. In the evaluation of the hypoglycemic effect of the crude methanol extract of A. cordifolia, the blood glucose level of the experimental animals was measured at zero hr using a glucometer (Bioland G-423 S). Then the control, standard and methanolic crude extract ( 200 and $400 \mathrm{mg} / \mathrm{kg}$ b.w.) were administered orally to the experimental animals with the help of feeding needle. At $1^{\text {st }}, 2^{\text {nd }}$ and $3^{\text {rd }}$ hrs after administration, the blood glucose level of the experimental animals was measured to observe the hypoglycemic effect of the test samples relative to control and standard groups.

For all bioassays, three replicates of each sample were used for statistical analysis and the values are reported as mean $\pm \mathrm{Sd}$.

\section{Results and Discussion}

The ${ }^{1} \mathrm{H}$ NMR spectrum $\left(400 \mathrm{MHz}, \mathrm{CDCl}_{3}\right.$ ) showed well resolved signals for 5 protons in the aromatic region (between $\delta 6.10$ and 7.70) and a three-proton singlet at $\delta 4.00$. Two doublets $(\mathrm{J}=9.6 \mathrm{~Hz})$ centred at $\delta 6.29$ and 7.59 were assigned to the typical $\mathrm{H}-3$ and $\mathrm{H}-4$ of a coumarin type carbon skeleton. The chemical shift for $\mathrm{H}-4(\delta 7.59)$ also suggested that $\mathrm{C}-5$ of the coumarin nucleus was non-oxygenated. The spectrum also displayed a broad singlet at $\delta 6.13$ which could be assigned to an $\mathrm{OH}$ proton at C-6 or C-7. It also revealed two singlets at $\delta 6.91$ and 6.84 (each of one proton intensity) assignable to protons at C-5 and C-8 or vice versa. However, the relatively weak signal for $\mathrm{H}-4$ at $\delta 7.59$ and another signal at $\delta 6.84$ demonstrated that it exhibited long range zigzag coupling with $\mathrm{H}-8$ appearing at $\delta 6.84$. In addition, there was a three-proton singlet at $\delta 4.00$ attributable to an aromatic methoxy group which could be placed either at C-7 or C-6. Therefore, the compound may have any of the following two structures: isoscopoletin (1) or scopoletin (4). Comparison of these values with those reported for scopoletin and isoscopoletin allowed to characterize compound $\mathbf{1}$ as isoscopoletin, which was further confirmed by co-TLC with authentic sample (Zheng-Xiang and Jing-Yu 2010).

The ${ }^{1} \mathrm{H}$ NMR spectrum (400 MHz, $\mathrm{CDCl}_{3}$ ) of umbelliferone (2) displayed signals for an $\mathrm{AB}$ system with proton resonances at $\delta 6.18(1 \mathrm{H}, \mathrm{d}, \mathrm{J}=9.2 \mathrm{~Hz})$, and $7.61(1 \mathrm{H}, \mathrm{d}, \mathrm{J}=9.2 \mathrm{~Hz})$, characteristic of H-3 and H-4 of coumarin nucleus. The spectrum also showed three one proton 
doublet centred at $\delta 7.29(1 \mathrm{H}, \mathrm{d}, \mathrm{J}=8.2 \mathrm{~Hz})$ and a double doublet at $6.74(\mathrm{~J}=8.2,2.0 \mathrm{~Hz})$, and another doublet $(\mathrm{J}=2.0 \mathrm{~Hz})$ at $\delta 6.77$ which could be assigned to $\mathrm{H}-5, \mathrm{H}-6$ and $\mathrm{H}-8$, respectively. A broad singlet of one proton intensity at $\delta 5.27$ was attributable to the $\mathrm{OH}$ proton at $\mathrm{C}-7$. Thus, the structure of the compound was elucidated as 7-hydroxycoumarin or umbelliferone (2), which was confirmed by comparison of its ${ }^{1} \mathrm{H}$ NMR spectral data with that published for umbelliferone (2) (Kim et al. 2006), as well as co-TLC with authentic sample.

The ${ }^{1} \mathrm{H}$ NMR spectrum $\left(400 \mathrm{MHz}, \mathrm{CDCl}_{3}\right)$ of the third compound was found to be identical to the spectrum of $\beta$-sitosterol. Similarly, co-TLC of this compound with previously isolated $\beta$ sitosterol (Chaturvedula and Prakash 2012) allowed to identify it as $\beta$-sitosterol.

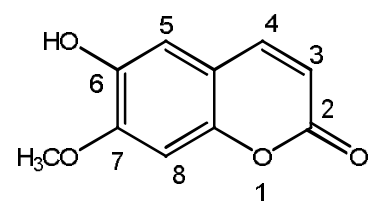

Isoscopoletin (1)

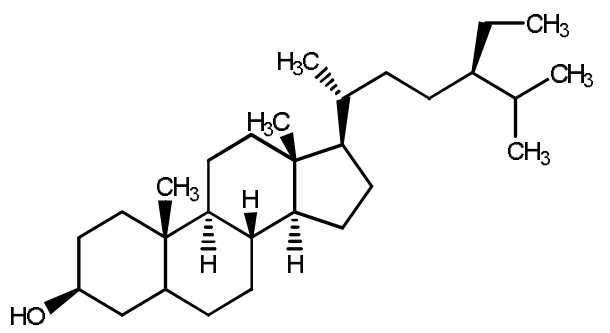

$\beta$-sitosterol (3)<smiles>O=c1ccc2ccc(O)cc2o1</smiles>

Umbelliferone (2)<smiles>COc1cc2ccc(=O)oc2cc1O</smiles>

Scopoletin (4)

Fig. 1. Chemical structure of isolated compounds from bark of A. cordifolia.

During screening for antimicrobial activity of different extractives (Faiza et al. 2015), the CTCSF extract showed highest antimicrobial potency against Sarcina lutea $(7.81 \mu \mathrm{g} / \mathrm{ml})$ followed by ME against Bacillus megaterium $(15.625 \mu \mathrm{g} / \mathrm{ml}$ ) (Table 1). No microbial growth was observed in the test tubes TM (containing medium only) and TMC (medium + test sample, no inoculum)

Table 1. Determination of $\mathrm{MIC}(\mu \mathrm{g} / \mathrm{ml})$ of test samples from bark of $\boldsymbol{A}$. cordifolia.

\begin{tabular}{lcccc}
\hline Test microorganism & \multicolumn{3}{c}{ MIC $(\mu \mathrm{g} / \mathrm{ml})$} & \multirow{2}{*}{ Ciprofloxacin } \\
\cline { 2 - 4 } & ME & PESF & CTCSF & \\
\hline Gram positive bacteria & & & & 0.38 \\
Bacillus cereus & 62.5 & 31.25 & 62.5 & 1.25 \\
B. megaterium & 15.625 & 31.25 & - & 0.62 \\
B. subtilis & 62.5 & - & - & 1.25 \\
Sarcina lutea & - & 62.5 & 7.81 & 0.31 \\
Gram negative bacteria & & & & 0.62 \\
Salmonella Typhi & 31.25 & 15.625 & - & 0.31 \\
Salmonella Paratyphi & - & - & 250 & \\
Shigella dysenteriae & - & - & 250 & . \\
\hline
\end{tabular}

MIC $=$ Minimum inhibitory concentration, $\mathrm{ME}=$ Methanol extract, PESF $=$ Petroleum soluble fraction and $\mathrm{CTCF}=$ Carbon tetrachloride soluble fraction of $A$. cordifolia. 
indicating that the medium and the test sample were not contaminated by microorganism. However, microbial growth was observed in test tube marked as TMI (medium + inoculums) revealing the fact that there was no problem with the sub cultured microorganisms.

The methanol extracts of $A$. cordifolia exhibited mild central analgesic activity at both doses of 200 and $400 \mathrm{mg} / \mathrm{kg}$ b.w., after 30, 60 and $90 \mathrm{~min}$ of tail immersion (Table 2).

Table 2. Effect of methanol extracts of $A$. cordifolia on tail immersion test in mice.

\begin{tabular}{|c|c|c|c|c|c|c|}
\hline \multirow{3}{*}{ Sample } & \multicolumn{6}{|c|}{ Average immersion time } \\
\hline & \multicolumn{2}{|c|}{ After $30 \mathrm{~min}$} & \multicolumn{2}{|c|}{ After $60 \mathrm{~min}$} & \multicolumn{2}{|c|}{ After 90 min } \\
\hline & $\begin{array}{c}\text { (Average } \\
\text { immersion } \\
\text { time } \pm \text { SD) }\end{array}$ & $\begin{array}{c}\% \\
\text { elongation }\end{array}$ & $\begin{array}{c}\text { (Average } \\
\text { immersion } \\
\text { time } \pm \text { SD) }\end{array}$ & $\begin{array}{c}\% \\
\text { elongation }\end{array}$ & $\begin{array}{c}\text { (Average } \\
\text { immersion } \\
\text { time } \pm \mathrm{SD} \text { ) }\end{array}$ & $\begin{array}{c}\% \\
\text { elongation }\end{array}$ \\
\hline Bark CTL & $4.35 \pm 0.13$ & & & & & \\
\hline STD & $8.90 \pm 0.24$ & 104.6 & & & & \\
\hline ME 1 & $4.53 \pm 0.35$ & 4.14 & $3.41 \pm 0.35$ & 5.90 & $2.08 \pm 0.53$ & 3.33 \\
\hline ME 2 & $4.67 \pm 0.23$ & 7.36 & $3.75 \pm 0.28$ & 16.46 & $2.56 \pm 0.22$ & 83.33 \\
\hline
\end{tabular}

$\mathrm{ME}=$ Methanol extract, $\mathrm{PESF}=$ Petroleum soluble fraction, $\mathrm{CTCF}=$ Carbon tetrachloride soluble fraction of A. cordifolia, $\mathrm{STD}=$ Standard drug morphine and $\mathrm{CTL}=$ Control group.

Methanol extract of $A$. cordifolia showed significant peripheral analgesic activity with per cent inhibition of 65.5 and $60.7 \%$ at $200 \mathrm{mg} / \mathrm{kg}$ and $400 \mathrm{mg} / \mathrm{kg}$ b.w. respectively (Table 3).

Table 3. Effect of methanol extracts of $A$. cordifolia on writhing test in mice.

\begin{tabular}{lccccc}
\hline $\begin{array}{l}\text { Animal } \\
\text { group }\end{array}$ & \multicolumn{3}{c}{ Number of writhing } & Average & $\begin{array}{c}\text { Inhibition } \\
(\%)\end{array}$ \\
\cline { 2 - 4 } CTL & M-1 & M-2 & M-3 & & - \\
STD & 28 & 30 & 26 & 28 & 72.6 \\
ME 1 & 8 & 6 & 9 & 7.67 & 65.5 \\
ME 2 & 11 & 9 & 9 & 9.67 & 60.7 \\
\hline
\end{tabular}

$\mathrm{ME}=$ Methanol extract, $\mathrm{PESF}=$ Petroleum soluble fraction, $\mathrm{CTCF}=$ Carbon tetrachloride soluble fraction of A. cordifolia . STD = Standard drug diclofenac, $\mathrm{CTL}=$ Control group, $\mathrm{M}-1,2,3=$ Mouse-1, 2 and 3, respectively.

The methanolic extract of $A$. cordifolia showed significant anti-diarrheal activity at the first, second, third and fourth hrs (Table 4).

Table 4. Antidiarrheal activity of extracts of $A$. cordifolia.

\begin{tabular}{lcccccccc}
\hline $\begin{array}{l}\text { Animal } \\
\text { group }\end{array}$ & $1 \mathrm{hr}$ & $\begin{array}{c}\% \\
\text { reduction }\end{array}$ & $2 \mathrm{hrs}$ & $\begin{array}{c}\% \\
\text { reduction }\end{array}$ & $3 \mathrm{hrs}$ & $\begin{array}{c}\% \\
\text { reduction }\end{array}$ & $4 \mathrm{hrs}$ & $\begin{array}{c}\% \\
\text { reduction }\end{array}$ \\
\cline { 2 - 9 } & 2.67 & & 4.0 & & 3.0 & & 0.33 & \\
CTL & 0.33 & 87.6 & 1.0 & 75 & 1.67 & 44.3 & 0 & 100 \\
STD & 0.52 & 80.5 & 0.91 & 77.3 & 1.88 & 37.3 & 0 & 100 \\
ME 1 & 0.75 & 71.9 & 0.67 & 83.2 & 2.5 & 16.67 & 0 & 100 \\
ME 2 & 0.75 &
\end{tabular}

ME = Methanol extract, $\mathrm{PESF}=$ Petroleum soluble fraction, $\mathrm{CTCF}=$ Carbon tetrachloride soluble fraction of A. cordifolia, $\mathrm{STD}=$ Standard drug loperamide and $\mathrm{CTL}=$ Control group. 
The crude methanol extract of $A$. cordifolia revealed significant hypoglycaemic activity at 200 and $400 \mathrm{mg} / \mathrm{kg}$ b.w. After $150 \mathrm{~min}$ of administration, the crude methanol extract displayed 53.6 and $29.3 \%$ reduction of blood sugar level at 200 and $400 \mathrm{mg} / \mathrm{kg}$ of body weight, respectively (Table 5).

Table 5. Hypoglycemic activity of extracts of $A$. cordifolia.

\begin{tabular}{lcccccccc}
\hline $\begin{array}{l}\text { Animal } \\
\text { group }\end{array}$ & $0 \mathrm{~min}$ & $\begin{array}{c}\% \\
\text { reduction }\end{array}$ & $30 \mathrm{~min}$ & $\begin{array}{c}\% \\
\text { reduction }\end{array}$ & $90 \mathrm{~min}$ & $\begin{array}{c}\% \\
\text { reduction }\end{array}$ & $150 \mathrm{~min}$ & $\begin{array}{c}\% \\
\text { reduction }\end{array}$ \\
\hline CTL & 5.70 & & 10.67 & & 7.33 & & 5.6 & \\
STD & 4.17 & 26.74 & 7.27 & 34.9 & 3.53 & 107 & 3.3 & 69.7 \\
ME-1 & 5.77 & 1.23 & 7.97 & 27.7 & 4.50 & 80.1 & 3.83 & 53.6 \\
ME-2 & 4.67 & 18.1 & 9.73 & 9.66 & 4.63 & 76.5 & 4.63 & 29.3 \\
\hline
\end{tabular}

$\mathrm{ME}=$ Methanol extract, $\mathrm{PESF}=$ Petroleum soluble fraction, $\mathrm{CTCF}=$ Carbon tetrachloride soluble fraction of A. cordifolia, $\mathrm{STD}=$ Standard drug metformin and $\mathrm{CTL}=$ Control group.

Adina cordifolia is a potential candidate for further chemical investigation, since it has significant antidiarrheal, hypoglycemic and peripheral analgesic activities. Besides isolating three simple compounds like isoscopoletin (1), umbelliefrone (2), and $\beta$-sitosterol (3), the observed antidiarrheal and peripheral analgesic activity justify the traditional use of the plant in diarhhoea, stomachache and headache.

\section{References}

Ahmed ZU, Hassan MA, Begum ZNT, Khandaker N, Kabir SNH, Ahmad M and Ahmed ATA 2009. Encyclopedia of Flora and Fauna of Bangladesh, Vol. 10, Angiosperm; Dicotyledons (RanunculaceaeZygophyllaceae). Asiatic Society of Bangladesh, Dhaka, Bangladesh. pp. 60-61.

Chaturvedula VSP and Prakash I 2012. Isolation of stigmasterol and $\beta$-sitosterol from the dichloromethane extract of Rubus suavissimus. Int. Curr. Pharm. J. 1: 239-242.

Durschlag M, Wurbel H, Stauffacher M and Von Holst D 1996. Repeated blood collection in the laboratory mouse by tail incision - modification of an old technique. Physiol. Behav. 60: 1565-1568.

Faiza T, Sikder MA, Sayeed MA, and Rashid MA 2015. Bioactivities of Murraya koenigii (Linn.) and Adina cordifolia (Roxb.). Bangladesh Pharm. J. 18: 25-29.

Ibrahim M, Hossain MA, Shajib, MS and Rashid MA. 2018. Preliminary phytochemical and pharmacological screenings of Plumbago indica L. and Alpinia conchigera Griff. Dhaka Univ. J. Pharm. Sci. 17: 73-79.

Islam S, Shajib MS, and Ahmed T 2016. Antinociceptive effect of methanol extract of Celosia cristata Linn. in mice. BMC Complement. Altern. Med. 16: 400.

Jennifer MA 2001. Determination of minimum inhibitory concentrations. J. Antimicrob. Chemother. 48 : 5-16.

Kaushik D, Kumar A, Kaushik P and Rana AC 2012. Analgesic and anti-inflammatory activity of Pinusrox burghii Sarg. Adv. Pharmacol. Sci. 2012: 245431.

Kim JS, Kim JC, Shim SH, Lee EJ, Jin W, Bae K, Son KH, Kim HP, Kang SS, and Chang HW 2006. Chemical constituents of the root of Dystaenia takeshimana and their anti-inflammatory activity. Arch Pharm. Res. 29: 617-623.

Mabberley DJ 2008. Mabberley's Plant Book (3rd Eds). Cambridge University Press.

Miah MM, Das P, Ibrahim Y, Shajib MS and Rashid MA 2018. In vitro antioxidant, antimicrobial, membrane stabilization and thrombolytic activities of Dioscorea hispida Dennst. Eur. J. Integr. Med. 19: 121-127.

Prakash V, Saxena S, Gupta S, Saxena AK, Yadav R and Singh SK 2015. Preliminary phytochemical screening and biological activities of Adina cardifolia. J. Microb. Biochem. Technol 7: 33-38. 
Shoba FG and Thomas M 2001. Study of antidiarrhoeal activity of four medicinal plants in castor-oil induced diarrhea. J. Ethnopharmacol. 76: 73-76.

Sikder MA, Sharmin T, Rahman AFMM, Haque MR, Rahman MS and Rashid MA 2013. Screenings of four medicinal plants of Bangladesh for bioactivities. Dhaka Univ. J. Pharm. Sci. 12: 59-62.

Turnidge JD, Ferraro MJ, Jorgensen JH 2003. Manual of clinical microbiology (8th Eds), Washington, American Society of Clinical Microbiology. p. 1103.

Zheng-Xiang X and Jing-Yu L 2010. Steroids and phenols from Sonchus arvensis. Chin. J. Nat. Med. 8: $267-$ 269.

(Manuscript received on 11 July, 2018; revised on 7 September, 2018) 